\title{
The Future of offshoring FDI in high-tech sectors
}

\author{
Yama Temouri $^{\mathrm{a}}$, Nigel L.Driffield ${ }^{1 \mathrm{a}}$, and Dolores Añón Higón ${ }^{\mathrm{b}}$ \\ ${ }^{a}$ Aston University, Birmingham, UK \\ ${ }^{b}$ University of Valencia, Valencia, Spain
}

\begin{abstract}
This paper examines what is still a relatively new phenomenon in the literature, the outsourcing / offshoring of high-technology manufacturing and services. This has become a concern for both policy makers and academics for two reasons. Firstly, policy makers have become concerned that the offshoring of high-technology sectors in the West will follow the more labour intensive sectors, and move to lower cost locations. Secondly, international business theory has tended to view low costs, and high levels of indigenous technological development as being the two main drivers of location advantage in the attraction of FDI. We show that this may not be the case for offshored high-technology manufacturing or services.
\end{abstract}

\footnotetext{
${ }^{1}$ Please address correspondence to Nigel Driffield, Economics and Strategy Group, Aston Business School, Aston Triangle, Birmingham, B4 7ET, United Kingdom; email: n.l.driffield@aston.ac.uk. Yama Temouri acknowledges support for his work from the ESRC.
} 


\section{Introduction}

In recent years a major concern of policy makers has been the extent to which globalisation has led to an increase in inequality. Initially this concerned the extent to which import competition from low cost countries was leading to a reduction in unskilled manufacturing jobs in the West. This was then overlaid with a debate concerning the globalisation of technology, and the extent to which technology would replace low skilled workers. Following on from this, has been the more recent concerns relating to international offshoring / outsourcing of activities, and the exporting of jobs from Europe and North America, to locations such as India, China or other parts of Asia. This issue has received a good deal of attention in the UK and US, but also in the rest of Europe. The debate in Germany for example has focussed on the negative effects of outsourcing and offshoring. The question of whether German MNEs relocate activities abroad at the detriment of activities at home is an important political issue and high on the policy agenda (Federal Ministry of Economics and Technology, 2007). Indeed, in the US, there was a considerable debate, conducted largely in the press between two leading economists, Gregory Mankiw (2004), who argued that offshoring was merely the latest manifestation of the long run gains from trade, and Alan Blinder, who argued that the long term ramifications of this, especially in terms of the potential paradigm shift in western manufacturing was only beginning to be understood ${ }^{2}$. There is a potentially even more pressing concern, that economies such as the UK, which have become very service sector driven, are now experiencing increasing share of services being offshored. This represents a significant share of employment and GDP raises new social and political concerns.

\footnotetext{
${ }^{2}$ See Blinder (2006)
} 
Both policy makers and IB scholars have recently become vexed by this issue. The concern for policy makers is clear, not only high-tech outsourcing / offshoring may lead to a reduction in employment, output and earnings, but it may also lead to key technological developments being made abroad rather than at home. While the West has witnessed high levels of competition from low cost locations, both in terms of international outsourcing through trade, and of offshoring through FDI, this has largely been in low-tech sectors, or in low value added activities in the more high-tech sectors. Driffield and Chiang (2009) for example highlight the huge reduction in Taiwanese employment that has occurred in low tech sectors as a result of offshoring from Taiwan to China. Couke and Sleuwaegen (2008) however offer a wider context. They demonstrate that offshoring is a defensive strategy, used by firms to counter the competitive effects of globalisation. This is essentially an extension of the efficiency seeking argument for offshoring, and Couke and Sleuwaegen (2008) argue that offshoring significantly reduces the probability of exit by Belgian firms. Couke and Sleuwaegen (2008) briefly discuss how offshoring can be seen as a an "offensive" strategy, but they do not distinguish between high tech and low tech activities. An issue for future research is to explore whether this conventional analysis of offshoring in terms of high tech firms or sectors. Key questions concern the drivers of offshoring, and what the limiting factors may be. Offshoring increasingly involves new product development, R\&D activities and new product design (Patel and Vega, 1999). This phenomenon also presents a new set of problems for IB scholars. Empirical work in this area has used relatively simple measures such as labour costs or revealed competitive advantage based on trade flows as measures of a more complex set of phenomena that tend to be labelled as location advantage (Dunning 1998). It is generally assumed that these factors will unambiguously attract FDI, irrespective of 
the specific motivation for the investment. However, it may be that for outsourcing / offshoring of more high-tech activities, other effects dominate.

The outsourcing / offshoring literature stresses the dominance of location in explaining the offshoring decision. However, for high-tech firms, firm specific knowledge or ownership advantages may dominate. A key issue for example is the ability to manage core technology across national boundaries, and, following Casson (2007) limit the leakage or spillover of technology to local firms. Spillovers from FDI may not be a central issue for a firm engaging in FDI in the traditional Vernon (1966) model, but it is crucial for firms considering the offshoring of high-technology. Equally, in this context, while one could envisage that a location minimum threshold of technological capacity is desirable, it may be that very high levels of indigenous technology may facilitate spillovers, thus discouraging offshoring investment. It is beyond the purpose of this paper to discuss the spillovers mechanisms in detail, as there are a number of survey papers, see for example Görg and Greenaway (2004), who list the main sources as: Formal technology exchange, mobility of employees between inward investors and domestic firms, assimilation of technology through supply chains, and more informal learning processes. While the MNE may be able to prevent the more formal of these, it is clear that the informal mechanisms are strongly related to the absorptive capacity of firms, see for example Girma (2005).

The purpose of this paper therefore is to discuss the recent outward FDI expansion from two angles. Firstly, we analyse the situation that has developed over the past ten years in advanced OECD countries, and secondly we provide some considerations on changes that may occur in the future. This is important, not only for policy makers at a national and regional level, but also for the future of IB theory. By 
exploring the recent FDI activities of firms from the advanced OECD countries, we make several contributions to the existing literature. Firstly, this paper provides firmlevel descriptive evidence on the location and activities of offshore investments using a panel of MNEs based in eight leading OECD countries and their foreign subsidiaries around the world between 1997 and 2006. Secondly, in line with the theoretical literature this study highlights the differences between low versus high cost destinations and the type of investment undertaken. This is a unique feature of our data set in that it allows us to link a parent firm's domestic operations with its subsidiaries across the world including whether the investment is of a horizontal or vertical nature.

Thirdly, the focus of the analysis will be on the high-tech sectors of the economy, which play an important role in terms of growth potential for any advanced economy, but have yet been unexplored in terms of offshoring or international outsourcing. It is thus imperative from an OECD perspective to see whether outward FDI from high-tech sectors is occurring at the detriment of home activities and the possible erosion of the skill base at home.

Finally, most of the previous studies focus on the manufacturing sector, either on aggregate or at the firm level ${ }^{3}$. However, the services sector includes knowledgeintensive industries which play an ever more important role in the structure and volume of outward FDI in advanced economies. To this end, this study contributes further by incorporating the high-tech service sector in the analysis.

The rest of the paper is organised as follows. Section 2 gives an overview of the arguments in previous empirical studies on the determinants of offshoring. Section

\footnotetext{
${ }^{3}$ This is due to the fact that micro-data for the service sector is not readily available for many countries.
} 
3 offers a description on how the data set is constructed and descriptive statistics, followed by the discussion of the empirical results. Section 4 concludes.

\section{Previous Analysis}

Theoretical perspectives on outsourcing, be it international or domestic are relatively straightforward. The fundamental basis is cost differences between producing an intermediate input internally, or purchasing it. Overlaid on that are the standard theoretical perspectives of agency theory and transaction cost analysis (see for instance, Antràs and Helpman, 2004). This is discussed in detail in Olsen (2006), though this literature largely ignores one of the fundamental determinants of transaction costs, risk. While agency theory can offer a perspective on the problems with managing arm's length contracts, the risks associated with international outsourcing may outweigh the benefits, especially in high-tech sectors where firm specific knowledge, whether patented or even uncodified is at a premium (SannaRandaccio and Veugelers, 2007) .

Theoretical perspectives on offshoring however must build on this. Görg and Hanley (2005) present an empirical analysis of the productivity impacts of offshoring, while Driffield et al. (2009) illustrate how offshoring FDI may be identified within a more general framework, and in turn linked to productivity and labour demand. However, all of this analysis is largely empirical, with little theoretical input beyond cost differences between locations. It is perhaps surprising that IB theory is not applied here more rigorously. For instance, the limits to internalisation are important within the context of offshoring. While it may well be the case that cost differences 
are significant between home and potential host country, the risks associated with attempting to manage technology across national boundaries, while preventing spillovers, may dictate that offshoring in high-tech sectors is limited. One can link this to the standard analysis of FDI within high-tech sectors that sees the MNE as an important vehicle for international technology transfer.

There is a well established literature in international business / technology management that has recognised that many of the world's largest firms carry out R\&D outside of their home country, but this typically is linked to ideas surrounding agglomeration of technological effort, or on the use of FDI in technology sourcing, such as the use of offshore facilities as "listening posts" (Budhwar et al., 2006; Almeida, 1996; Håkanson and Nobel, 1993; Pearce, 1999; Cantwell and Janne, 1999). This analysis however is based on the supposition that these FDI flows are essentially between developed countries, typically either transatlantic, or intra EU investments. Also, the analysis is largely based on the "triad" model of international production, with the US, the richest western European countries, and Japan dominating international production, and merely outsourcing or offshoring low level activities to neighbouring low wage countries.

The picture now however is far removed from this. Many high-tech firms from these locations are relocating both $R \& D$ and $R \& D$ related activities to South and South East Asia, and to Eastern Europe (e.g., Budhwar et al., 2006). Equally, there is a high level of intra-EU FDI in high-tech sectors, which traditionally may have been thought of in the context of technology sourcing, but may actually be offshoring that has been hitherto ignored. In this paper we aim to explain these differences between firms, as well as between countries and industries. As Olsen (2006) highlights, there is 
very little understanding of what the effects of outsourcing may be. Where analysis is carried out, see for example Driffield et al. (2009) or Marin (2006) the focus is on the impact of the outsourcing that is observed at a given point in time, rather than on the theoretical explanations of it, and what we can learn going forward. Hijzen et al. (2005) for example highlight the importance for outsourcing in terms of domestic labour demand, but explain this merely in terms of cost differences in the supply of intermediate inputs. It should also be pointed out that this literature is based on international outsourcing (i.e. purchasing inputs from abroad instead of at home) rather than explaining the location of outward FDI in this context.

However, theoretically, the limiting factor in offshoring high-tech activities is not the cost difference. It is well established that countries such as India, China, Hungary or the Czech Republic have highly skilled workforces that can undertake high value added activities at a lower cost than Japan, Germany or the US. Neither in many cases is it the cultural or physical distance between the home and potential host country. Rather, it is the agency problem and risk associated with transferring key firm specific assets or technology to other countries. It is well understood in the literature that such cases generate the greatest spillovers for domestic firms, and is contrary to the interests of the parent. This builds on the theory of international technology transfer, and the more applied spillovers literature, that highlights hightech FDI to countries with sufficient absorptive capacity, as being those projects that generate the greatest technology transfer and spillover effects for the host. In some cases it may be optimal for a firm to engage in this form of FDI, where they are seeking, a la Dunning (1979) or Vernon (1966) to exploit assets or technology in new markets. Long standing analysis suggests that such projects are most successful where 
these investments become embedded in the local production system (see for example Caves, 1985) and that in such cases the benefits to the host country are maximised.

This is a very different scenario for outsourcing or offshoring high-tech activities, where the aim is to retain control of the technology, and limit spillovers. Casson (2007) discusses this in some detail, highlighting the desire of firms to minimise spillovers rather than limit them.

\section{Analysis}

\subsection{The data.}

Table 1 lists the countries and industries in our sample. The focus in this paper is on firms from the most advanced OECD countries which operate in hightechnology industries. A feature of "high-tech" industries is that they possess high levels of identifiable technology in the form of $R \& D$ and tacit knowledge which is intangible in nature. Such industries are seen as engines for growth in any economy and thus the threat of relocation of employment from high-tech industries makes this a highly sensitive issue, both in a political and economic sense.

Our data is taken from Orbis, a rich firm-level dataset, provided by Bureau van Dijk, which is an electronic publishing and consultancy firm. A growing number of researchers have used this data set in recent years to analyse various economic issues, including Helpman et al. (2004), Budd et al. (2005) and Konings and Murphy (2006). It offers detailed financial and other operational information on private and public companies around the world. The data set covers the period 1997-2006, including a total of 5,169 OECD MNEs, of which 2,594 are manufacturing firms and 2,575 are services firms. These MNEs have a network of 9,055 subsidiaries located across the world. 
$<$ Table 1 here>

Table 2 shows the distribution of parent firms and their subsidiaries across the various countries and regions. The United States, France, Germany and the UK combined host 75.9 per cent of the parent firms in the sample. While Sweden, the Netherlands, Belgium and Japan each host from 3.3 to 8.5 per cent of the parent firms. With regards to the subsidiaries, the EU-15 region holds the majority of subsidiaries at 67 per cent followed by North America and Eastern Europe at 13.6 and 6.4 per cent, respectively. Locations least attractive are Latin America, Asia, Africa, the Middle East and Oceania, ranging from 0.4 per cent to 5.7 per cent of all subsidiaries.

The lower panel of table 2 illustrates the sector distribution of parent and subsidiary firms across the manufacturing and services sectors. Of all manufacturing firms in the sample, Germany, France, UK and the US host the majority of parent firms (76 per cent) which is followed by the Netherlands, Sweden, Belgium and Japan. In terms of service firms, parent firms are mostly located in Germany, UK, France and the US.

With regards to the distribution of subsidiaries, the majority is located in the EU and North America. The EU-15 and Other Europe (i.e. Switzerland and Norway) have a lower percentage of manufacturing parent firms compared with service parent firms whereas for the other regions the opposite is true. On the bottom of the table, one can see that around a third (23.4 per cent) of the manufacturing parent firms have subsidiaries in only the manufacturing sector, 40.6 per cent in only the services sector and 36 per cent have subsidiaries in both the manufacturing and services sector. The majority of services parent firms have their subsidiaries in the services sector only, 4.2 
per cent in the manufacturing sector only and a 26.9 per cent in both the manufacturing and services sector.

$<$ Table 2 here $>$

Table 3 shows the distribution of parent firms and their investment location by firm size. Across the five size bands, the location choice of MNEs is fairly consistent. Most investments are undertaken within the EU-15 and North America (at least 85 per cent). Again, a significant portion of investment is attracted to Eastern Europe, especially in the manufacturing sector. For the service sector, Eastern Europe and other Europe (i.e. Norway and Switzerland) seem to be equally attractive. Interestingly, distance does seem to play an important part for smaller MNEs which have lower shares of their investments in far-away destinations, such as Latin America, Asia, Africa and Oceania.

$<$ Table 3 here>

\subsection{Initial Discussion}

Figure 1 shows the average annual growth rates of workers employed by the parent firm and their subsidiaries in various regions of the world for the period 19972006. Albeit considerable heterogeneity, the figure shows that the rate of growth was increasing up until 2000. It then fell for two years before increasing again more moderately until 2004 and since then it has been fairly constant. High-tech parent firms grew on average at around 15 per cent annually at the beginning of the period which fell to around 5 per cent in latter years of the sample period. On a regional level, we can see that subsidiaries in Eastern Europe had the highest rates of growth throughout most of the period. The most volatile regions in terms of employment 
growth were other developing countries, which include Asian countries, Africa, Latin America and the Middle East. The other regions, namely EU-15, North America and other developed countries within the OECD show a relatively more modest trend which is in the figure lies between that of Eastern Europe and other developing countries.

<Figure 1 here>

Table 4 shows the average growth rate of workers employed over the sample period. For parent firms in the manufacturing sector, this ranges from 0.6 per cent in Japan to 5.9 per cent in Belgium. However, the growth rates are significantly higher for parent firms in the services sector, ranging from 11.1 per cent in Japan to 26.9 per cent in Belgium. In terms of the growth rates of subsidiaries, higher rates are observed among subsidiaries mainly in developing countries. For example, subsidiaries in Eastern Europe, Latin America and Asia have grown up to a maximum of 35 per cent. Much smaller rates of growth are to be found in subsidiaries located in Africa, the Middle East and Oceania. Subsidiaries located in the EU-15 and North America have also more modest growth rates but nowhere near the ones in some developing countries.

In comparison to the above results, table 5 also shows average growth rates for parents in the low-tech sectors of OECD countries, together with their subsidiaries around the world. The main difference is that the growth rates of employment are not as heterogeneous. For example, both for manufacturing and services, parent and subsidiary growth rates are not as volatile across countries as for the high-tech sector. One reason might be, that the sample of industries regarded as low-tech is larger than for the high-tech sector, thus having a larger set of subsidiaries as well. This has the 
effect that a number of big investments in the high-tech industry in say Eastern Europe in any one year might have a bigger effect on the growth rates for that region. Nevertheless, what is consistent across both sectors is that the employment rates of growth are higher in some developing regions, such as Eastern Europe.

$<$ Tables 4 and 5 here>

\subsection{Econometric analysis of the probability to offshore high-tech activities}

Finally, we extend the descriptive and bivariate analysis by examining the propensity to engage in offshoring by estimating the following model:

$$
\begin{aligned}
& \text { Offshore }_{i t}=\alpha_{0}+\beta_{1} \text { size }_{i t-1}+\beta_{2} \text { prod }_{i t-1}+\beta_{3} \text { capital }_{i t-1}+\beta_{4} \text { profit }_{i t-1}+\beta_{5} \text { cash }_{i t-1} \\
& +\beta_{\Psi} \Psi_{i t-1}+\alpha_{i}+\mu_{t}+\varepsilon_{i t}
\end{aligned}
$$

where Offshore represents the decision of a high-tech firm to engage in offshoring, that is engaging in FDI in upstream sectors to low cost locations. Equation (1) is derived from the literature discussed above, and includes the following variables:

Firm size is a measure of the firms' ability to manage diverse and complex assets, measured in terms of employment. Productivity ${ }^{4}$ represents the standard measure of the internal efficiency of the firm. Profitability (defined as Earnings before Interest and Taxes) is a measure of the financial well being of the firm. Capital intensity is measured as total assets / turnover, and is employed as the standard measure of firm specific assets or knowledge. Finally, cash flow is included, as a measure of the ability of the firm to fund new investments (Baker et al. 2003). The

\footnotetext{
${ }^{4}$ For comparison across countries this is measured as labour productivity: value added per employee
} 
potential importance of cash in explaining offshoring highlights one of the differences between this type of FDI, and the more researched market seeking or technology exploiting FDI, that typically is funded by equity, or commonly in recent years, debt. This is also a pointer to the future flows of different types of FDI, with debt more difficult to obtain and service since the onset of the credit crunch.

The general outsourcing / offshoring literature suggests that firm size is expected to be positive, while the effects of labour productivity and firm performance are rather more ambiguous. In general, these variables are positively associated with the ability of a firm to undertake outward $\mathrm{FDI}^{5}$. However, the outsourcing / offshoring literature that examines the propensity of firms in low-technology sectors to relocate to low cost locations suggests that these variables will be negative, suggesting the low performance firms are those with the greatest cost pressure, and most likely to relocate. However, this is less likely to be the case for high-technology firms, where the ability to manage high productivity capacity across national boundaries may be more important. As such, it is likely to be the better performing firms that engage in offshoring activities. Capital intensity is also expected to be positive, indicative of the quality of the firm specific assets, with again better firms looking to engage in outsourcing / offshoring.

In the sector specific regressions, we include a measure of labour costs as an additional variable, to capture whether firms from high cost countries are more likely to engage in outsourcing / offshoring.

We estimate this model for a set of eight countries, both jointly and separately. The choice of advanced OECD countries was determined according to the availability

\footnotetext{
${ }^{5}$ For a more general discussion of this point see Bhaumik et al. (2009) and the references therein.
} 
of sufficient number of parent and subsidiary matches and which included the appropriate set of variables used in the analysis.

\subsection{Results}

Moving from the informative, but relatively simple bivariate analysis, we now move to a model of offshoring activity in high-tech sectors, building on analysis of Girma and Görg (2004), Marin (2006) and Görg et al. (2008). The fundamental premise of this is that one can explain the offshoring decision in terms of a few key variables, linked to internal and external efficiency (productivity and profitability), firm size, the availability of funds to finance the investment, capital intensity, and firm specific knowledge.

Table 6 shows estimates of a selection model represented by equation (1) where the dependent variable is a dichotomous variable between firms that offshore and firms that do not. The appropriate way to estimate this is through a panel probit model. This approach is now relatively common in the modelling of the FDI decision; see for example Paul and Wooster (2008) for a recent example. The advantages of the panel nature of the data are two fold. Firstly, the probit model, as is well understood, controls for the dichotomous nature of the dependent variable, and secondly the panel structure of the data controls for firm-specific and time invariant unobserved factors that might influence the decision to invest overseas using firm-specific fixed effects. Finally in order to mitigate endogeneity problems of the explanatory variables, we lag them by one time period such that, for example, the profits in period $t-1$ affect the firm's decision to offshore in period $t$. 
The first thing to note about the results presented in table 6 is that the models are remarkably consistent across all countries. Capital intensity, size and productivity are all uniformly associated with an increase in offshoring, with the exception of size for the UK. Profitability is either positive or insignificant in all cases, and cash flow is either positive or insignificant in all cases with the exception of Germany. Germany is of course unique among these countries in that it has a potential low cost location within its borders, the East of the country still having significantly lower labour costs than the West.

The results are supportive of our basic hypothesis. Firm performance, particularly internal performance measured through productivity is positively associated with offshoring in high-technology sectors. This suggests that the better performing firms are driven to engage in offshoring of high-technology activities. This differs significantly from the findings of studies on low-tech sectors which suggest that often firms experiencing low productivity at home seek to offshore unproductive activities.

Taken together, cost seems to be a very minor consideration for outsourcing / offshoring in high-tech sectors, compared with the ability to manage assets, and develop firms' specific knowledge. The descriptive results presented in table 2 and table 3 indicate that Western Europe and the US were the largest recipients of offshore investment in our sample of high-tech MNEs. In addition, the findings presented in table 6 and 7 suggest that firm's specific assets, such as the efficiency and ability to manage diverse and complex assets, are key in determining the decision to offshore. 


\section{$<$ Tables 6 and 7 here>}

\section{Implications for the Futures of offshoring FDI}

The issue of offshoring / outsourcing has attracted the attention of policy makers in both host and source countries. A speech on "unlocking Europe's growth potential" by the president of the European Commission in 2006 focussed on the location, and re-location of activity as the biggest single challenge facing Europe. In the US, the Senate recently passed a bill to impose curbs on federally-funded outsourcing, with the new US President backing this call. In response, the Indian Prime Minister claimed that exporting jobs from the West to India will eventually create more employment in economies like the US. All of this highlights the importance for local, national and international development of location decisions of firms, and FDI flows more generally. It is clear that emerging and transition countries are still seeking to attract offshoring FDI, though there are numerous reasons to believe that it may have peaked.

One of the most influential papers in IB in the last ten years is Dunning (1998), which highlights the importance of location in explaining, not only the strategic decisions of firms at the top of the supply chain, but also where to locate other links in the chain. This, allied with a stronger theoretical focus on outsourcing has dramatically changed the lens through which the eclectic paradigm is viewed, from being one focussing on ownership advantages and international technology transfer, to a more balanced assessment of location. In terms of the competitiveness of national economies, this theoretical perspective raises additional concerns. While the outsourcing or offshoring of low skill activities raises concerns about inequality, social immobility and unemployment, the prospect of the outsourcing of more high value added activities raises concerns about long term productivity growth and 
national competitiveness. Theoretically, the same forces that drive the relocation of unskilled activity to low cost regions, drive high-tech activities away from high cost regions such as the south east of England, southern Germany or the Eastern States of the US, to Eastern Europe, China or India. Equally, the restrictions on this placed by distance, in terms of outsourcing from the US to China, for example, do not occur in terms of Western Europe to say the EU accession countries.

The limited evidence on the link between outward FDI and firm performance, or the work of Couke and Sleuwaegen (2008) however suggests that, contrary to popular opinion, offshoring may generally be beneficial (or at least not detrimental) to productivity and employment within firms operating in advanced OECD countries (Barba Navaretti and Venebles, 2004). Although the dynamic processes by which firm performance is enhanced are complex and can take a number of forms, empirical results indicate that offshoring can on average be a source of productivity and employment growth.

The pattern of offshoring is not a simple story of just giant MNEs relocating a large number of jobs to low-wage countries at the detriment of home workers left unemployed. Rather, the vast majority of outward FDI is located in other advanced OECD countries by SMEs as well as giant MNEs. It is important to note that a whole variety of factors are taken into account by international firms in search for greater efficiency and growth. In this regard, relative wages are surely a determinant but not the key driver of all types of long term investment decisions. Costs interact with factors such as infrastructure (social, economic and political, skills mix of workers) and the type of investment (horizontal or vertical) to be offshored among many others. 
The general assumption in the offshoring / outsourcing literature is that it will continue unabated, at least in terms of the pressures for the relocation of low cost activities. This literature fails to make several key distinctions. Firstly, transport costs continue to rise, and the security problems of transporting goods through the Indian ocean appear to be increasing. Secondly, there is evidence at the time of writing that support for western firms in the form of grants or beneficial loans are being linked to employment retention at home, and in some cases even to retrenchment. As such, it is possible that the pressures for continued outsourcing may decline.

This however potentially contrasts with the service sector. Much of the offshoring / outsourcing in the service sector requires much less transporting of goods, but services that can be transferred electronically. As such, the analysis presented here would suggest that this is likely to become more attractive as long as the host countries have developed modern and reliable IT infrastructures. However, it is also clear that there are limits to this, not just in terms of IPR protection, but also the extent to which services such as accountancy or law can easily be traded across borders with different regulatory or institutional regimes.

There is a further potential limit on the scale of offshoring FDI in the near future, and that applies to all forms of FDI. Increasingly over the past twenty years, more and more FDI has been financed by debt. Since the economic downturn of 2008, debt has been more expensive, and harder to obtain. As a result, FDI is starting to decline. While FDI associated with offshoring may be more likely than other forms of FDI in a recession, financing of new investment is less likely, irrespective of the motive.

Overall, the prospects for continued growth in offshoring, and in particular the continued expansion of the range of activities undertaken in such locations may not be 
as strong as has hitherto been anticipated. The rationale for this is derived from both theoretical and empirical analysis of offshoring / outsourcing. In the first instance, the transactions costs associated with offshoring / outsourcing high-tech activities may preclude this from developing, while the economic downturn may reduce the scope for firms to engage in FDI at the same rates as historically been the case.

\section{Conclusions}

The purpose of this paper is to examine a phenomenon that, despite some well rehearsed examples is relatively uncommon at present. While much of the analysis applied to outsourcing / offshoring in general, or in low technology sectors still holds true, our study highlights several differences. Firstly, while costs are important, and firms from higher cost locations are more likely to engage in offshoring, they in no way dominate other considerations. There is a good deal of evidence that suggest that the better performing firms, in terms of both productivity and profitability are more likely to engage in this form of offshoring, and that while cost does partly explain this, there are other factors that may be more important than costs. Equally, larger firms, and firms with high levels of capital intensity are also more likely to engage in offshoring in high-technology sectors. These results, taken together, suggest that it is the ability to manage technology flows across countries that is the largest key determinant of offshoring by high-technology firms. Equally, they fund this activity through cash flow and profits.

The major policy concern for the source country with this type of FDI, is that key assets or technology are being moved to lower cost locations. This is essentially an extension to the arguments that have been made with respect to low cost activities being moved abroad. In this case the major concern is increasing unemployment 
amongst unskilled workers in richer countries. This concern has been exacerbated by the so called "hollowing out" phenomenon in Japan, where large sections of very long and complex supply chains have relocated from Japan to other parts of Asia.

A valid question therefore is the extent to which outsourcing / offshoring in high-tech activities is merely the next stage in globalisation of production, with the technological base of the richest countries under threat, as well as the well paid jobs of skilled workers. However, these results suggest that the scale of this phenomenon, for the moment at least is rather limited. Firstly, costs are not a driving factor in this type of FDI, compared with say the ability of a firm to manage its technology. There are clearly risks attached to offshoring high-technology sectors, the greatest of which are spillovers or technology transfer to local firms.

These results would also suggest that from the perspective of the host country, the protection of property rights and shareholders returns are important in attracting high-tech activities as well as the extent to which adequate IT infrastructures are in place. Institutions and governance designed to protect property rights are likely to prevent unintended technology transfer or spillovers to the domestic sector, which would be a major concern in these sectors. Extending this, as low cost locations improve their indigenous technological base, they may become less attractive locations for offshored high-technology activities. There is a large literature that shows how absorptive capacity plays a crucial role in determining the scale and scope of spillovers from FDI, and as absorptive capacity in host countries improve, so does the possibility of technology leaking out to local firms. 
These findings have several implications for the future of IB theory. Firstly, that institutions are likely to matter in many more ways than is currently understood. IB has recognised that good governance at the firm level is important in the post Enron world, and equally that the protection of property rights is important for attracting inward investment. However, most conceptual frameworks, developed from the investment cycle theory for example, assume that as a country becomes more technologically advanced, it will attract more technologically advanced FDI. While this study does not completely refute this, it does highlight several limits to the process, in terms of intellectual property rights, and the extent to which these allow firms to manage core technology across national boundaries.

\section{References}

Almeida P (1996) 'Knowledge sourcing by foreign multinationals: patent citation analysis in the US semiconductor industry' Strategic Management Journal, 17 (Special issue), 155-65.

Antràs, P., and Helpman, E. (2004) Global Sourcing, Journal of Political Economy, 112(3), 552-580.

Baker, M., Stein, J.C. and Wurgler, J. (2003) When does the market matter? Stock prices and the investment of equity-dependent firms, Quarterly Journal of Economics, 118, 969-1005

Barba Navaretti, G. and Venables A. (2004) 'Multinational Firms in the World Economy. Princeton University Press

Bhaumik, S., Driffield, N.L. and Pal, S (2009) Does Ownership Structure Affect Outward FDI? The Case of Indian Automotive and Pharmaceutical Sectors. Presented at AIB-UK conference, 2008. (Currently under final round or R\&R at JIBS)

Blinder, A.S. (2006) Offhsoring: The next industrial revolution? Foreign Affairs 85(2). http://www.foreignaffairs.org/2006/2.html.

Budhwar, P., Luthar, H., and Bhatnagar, J. (2006) Dynamics of HRM Systems in BPOs Operating in India. Journal of Labor Research, XXVII (3), 339-360.

Budd, J.W, Konings, J. and Slaughter, M.J. (2005) 'Wages and International Rent Sharing in Multinational Firms', The Review of Economics and Statistics, 87 (1), 73 84. 
Cantwell J and Janne O (1999) 'Technological globalisation and innovation centres: the role of technological leadership and location hierarchy' Research Policy, 28, 11944.

Casson, M.C. (2007) 'Multinational Enterprises: Their Private and Social Benefits and Costs', World Economy, 30(2), 308-328.

Caves, R. (1985) International trade and industrial organization: problems, solved and unsolved. European Economic Review, 28, 377-395.

Driffield, N. and Chiang, P.C. (2009) The Effects of Offshoring to China: Reallocation, Employment and Productivity in Taiwan> international Journal of the economics of business. 16 (1), pp 19-38.

Driffield N and Love J H (2007) 'Linking FDI Motivation and Host Economy Productivity Effects: Conceptual and Empirical Analysis', Journal of International Business Studies, 38, 460-473.

Driffield, N. Love, J. and Taylor, K. (2009) 'Productivity and labour demand effects of inward and outward FDI in the UK', Manchester School, 77 (2) pp 171-203.

Dunning, J. H. (1979). Explaining changes of international production: In defence of eclectic theory. Oxford Bulletin of Economic and Statistics, 41(4), 269-296.

Dunning, J. H. (1998) 'Location and multinational enterprise: A neglected factor', Journal of International Business Studies. 29(1), 45-66.

Fisch, J.H. (2003) Optimal Dispersion of R\&D Activities in Multinational Corporations with a Genetic Algorithm. Research Policy, 32, 1381-1396.

Girma, S (2005) Absorptive Capacity and Productivity Spillovers from FDI: A Threshold Regression Analysis. Oxford Bulletin of Economics \& Statistics Volume 67(3), 281-306

Girma, S. and Görg, H. (2004)., "Outsourcing, Foreign Ownership and Productivity: Evidence from UK Establishment Data", Review of International Economics, 12 (5), 817-832.

Görg, H. and Greenaway, D. (2004) Much Ado About Nothing? Do domestic Firm Really Benefit from Foreign Direct Investment? World Bank Research Observer, (2004/2): 191-197.

Görg and Hanley (2005) 'International outsourcing and productivity: evidence from the Irish electronics industry', North American Journal of Economics and Finance, 16, 255-269.

Görg, H., A. Hanley and E. Strobl (2008) 'Productivity effects of international outsourcing: Evidence from plant level data', Canadian Journal of Economics, 41(2), 670-688.

Håkanson, L. and Nobel, R. (1993) "Determinants of foreign R\&D in Swedish multinationals", Research Policy, 22, 397-411.

Harrison, A. and McMillan, M. (2007). 'On the links between globalization and poverty,' Journal of Economic Inequality, 5(1), 123-134.

Helpman, E., Melitz, M.J. and Yeaple, S.R. (2004) 'Export versus FDI with heterogeneous Firms', American Economic Review, 94(1), 300-316. 
Hijzen, A., Görg, H. and Hine, R. C. (2005) 'International Outsourcing and the Skill Structure of Labour Demand in the United Kingdom', Economic Journal, 115, 860-78.

Konings, J. and Murphy, A. (2006) 'Do Multinational Enterprises relocate employment to Low-Wage Regions? Evidence from European Multinationals', The Review of World Economics, 142(1), 1-20.

Mankiw, N. (2004), 'The Economic Report of the President', Council of Economic Advisors, Washington, DC, February 2004.

Marin, D. (2006) 'A New International Division of Labor in Europe: Outsourcing and Offshoring to Eastern Europe', Journal of the European Economic

Association, 4, 612-622.

Olsen, K.B. (2006) 'Productivity Impacts of Offshoring and Outsourcing: A Review,' OECD Science, Technology and Industry Working Papers, 2006/1.

Patel, P. and Vega, M. (1999). 'Patterns of Internationalisation of Corporate Technology: Location vs. Home Country Advantages.' Research Policy, 28, 144-155

Paul, D.L. and Wooster, R.B (2008)Strategic investments by US firms in transition economies Journal of International Business Studies, 39, 249-266.

Pearce R D (1999) 'Decentralised R\&D and strategic competitiveness: globalised approaches to generation and use of technology in multinational enterprises (MNEs)' Research Policy, 28, 157-78.

Sanna-Randaccio, F. and Veugelers, R. (2007). Multinational knowledge spillovers with decentralised R\&D: a game-theoretic approach, Journal of International Business Studies, 38, 47-63.

Simpson, H. (2007) 'Investment abroad and adjustment at home: Evidence from UK Multinational Firms', IFS working paper 07/07.

Vernon, R. (1966) 'International investment and international trade in the product cycle', Quarterly Journal of Economics, vol.80, pp.190-207. 
Table 1 Sample of Countries and Industries

\begin{tabular}{cl}
\hline Country & \multicolumn{1}{c}{ High-technology Industry } \\
\hline \hline & \multicolumn{1}{c}{ Manufacturing } \\
Belgium & Pharmaceuticals \\
Germany & Office machinery and computers \\
France & Radio, television and communication \\
Sweden & equipment and apparatus \\
Netherlands & Manufacture of medical, precision and optical \\
United Kingdom & instruments, watches and clocks \\
United States & Aircraft and Aerospace \\
Japan & Service sector \\
& Telecommunications \\
& Computer and related activities \\
& Research and Development \\
\hline
\end{tabular}


Table 2 Distribution of MNEs and Subsidiaries by Country and Sector (in \%)

\begin{tabular}{|c|c|c|c|c|c|}
\hline Parent firms & \multicolumn{2}{|c|}{ Frequency } & Subsidiaries & \multicolumn{2}{|c|}{ Frequency } \\
\hline Belgium & \multicolumn{2}{|c|}{5.5} & EU 15 & \multicolumn{2}{|c|}{67.1} \\
\hline Germany & \multicolumn{2}{|c|}{15.9} & Other Europe & \multicolumn{2}{|c|}{3.5} \\
\hline France & \multicolumn{2}{|c|}{11.6} & Eastern Europe & \multicolumn{2}{|c|}{6.4} \\
\hline Sweden & \multicolumn{2}{|c|}{6.8} & North America & \multicolumn{2}{|c|}{13.6} \\
\hline Netherlands & \multicolumn{2}{|c|}{8.5} & Latin America & \multicolumn{2}{|c|}{5.7} \\
\hline United Kingdom & \multicolumn{2}{|c|}{14.8} & Asia & \multicolumn{2}{|c|}{2.3} \\
\hline United States & \multicolumn{2}{|c|}{33.6} & Africa \& Middle East & \multicolumn{2}{|c|}{1} \\
\hline Japan & \multicolumn{2}{|c|}{3.3} & Oceania & \multicolumn{2}{|c|}{0.4} \\
\hline Total & \multicolumn{2}{|c|}{100} & & \multicolumn{2}{|c|}{100} \\
\hline \multicolumn{6}{|c|}{ Sector distribution of parent and subsidiary firms } \\
\hline Parent firms & Manu' & Services & Subsidiaries & Мапи' & Services \\
\hline Belgium & 6.2 & 4.9 & EU 15 & 50.0 & 71.4 \\
\hline Germany & 18.5 & 13.4 & Other Europe & 2.9 & 3.9 \\
\hline France & 13.7 & 9.5 & Eastern Europe & 8.6 & 6.0 \\
\hline Sweden & 5.1 & 8.5 & North America & 20.5 & 12.2 \\
\hline Netherlands & 7.5 & 9.6 & Latin America & 12.0 & 4.1 \\
\hline United Kingdom & 10.8 & 18.8 & Asia & 3.9 & 1.8 \\
\hline United States & 33.3 & 34.0 & Africa \& Middle East & 1.4 & 0.4 \\
\hline Japan & 4.9 & 1.3 & Oceania & 0.7 & 0.2 \\
\hline Total & 100 & 100 & & 100 & 100 \\
\hline \multirow[t]{2}{*}{ Parent } & \multicolumn{5}{|c|}{ Subsidiary } \\
\hline & \multicolumn{2}{|c|}{ Manufacturing } & Services & \multicolumn{2}{|c|}{ Both } \\
\hline Manufacturing & \multicolumn{2}{|c|}{23.4} & 40.6 & \multicolumn{2}{|c|}{36.0} \\
\hline Services & \multicolumn{2}{|c|}{4.2} & 68.9 & \multicolumn{2}{|c|}{26.9} \\
\hline
\end{tabular}

Note: Manu' -manufacturing. Other Europe = Norway and Switzerland.

Source: Authors' calculations using Orbis database. 
Table 3 Distribution of MNEs and their investment locations by Firm Size (in \%)

\begin{tabular}{|c|c|c|c|c|c|c|c|c|}
\hline & \multicolumn{8}{|c|}{ High-tech Manufacturing } \\
\hline & EU-15 & $\begin{array}{l}\text { Other } \\
\text { Europe }\end{array}$ & $\begin{array}{l}\text { Eastern } \\
\text { Europe }\end{array}$ & $\begin{array}{c}\text { North } \\
\text { America }\end{array}$ & $\begin{array}{c}\text { Latin } \\
\text { America }\end{array}$ & Asia & $\begin{array}{c}\text { Africa \& } \\
\text { Middle } \\
\text { East }\end{array}$ & Oceania \\
\hline \multicolumn{9}{|l|}{ No of } \\
\hline$<25$ & 75.6 & 6.2 & 12.4 & 14.9 & 7.4 & 2.9 & 0.4 & 0.0 \\
\hline $25-49$ & 77.3 & 1.9 & 7.7 & 17.9 & 4.8 & 1.4 & 0.5 & 0.0 \\
\hline $50-99$ & 75.4 & 2.7 & 8.8 & 19.9 & 3.4 & 2.0 & 1.3 & 0.3 \\
\hline $100-249$ & 71.1 & 2.8 & 9.3 & 27.4 & 6.4 & 3.8 & 0.8 & 0.2 \\
\hline$>250$ & 68.9 & 8.2 & 12.5 & 35.3 & 7.2 & 8.7 & 2.8 & 0.8 \\
\hline & \multicolumn{8}{|c|}{ High-tech Services } \\
\hline \multicolumn{9}{|c|}{$\begin{array}{l}\text { No of } \\
\text { Employees }\end{array}$} \\
\hline$<25$ & 77.1 & 7.9 & 7.9 & 9.4 & 2.5 & 0.5 & 0.2 & 0.5 \\
\hline $25-49$ & 80.3 & 5.9 & 3.9 & 13.4 & 1.3 & 1.6 & 0.0 & 0.0 \\
\hline $50-99$ & 82.6 & 6.9 & 6.0 & 14.7 & 0.6 & 1.2 & 0.3 & 0.6 \\
\hline $100-249$ & 84.5 & 3.6 & 3.4 & 17.5 & 2.8 & 2.1 & 0.5 & 0.0 \\
\hline$>250$ & 78.4 & 7.3 & 5.5 & 22.1 & 9.5 & 3.0 & 1.5 & 0.8 \\
\hline
\end{tabular}

Source: Authors' calculation using the Orbis data 


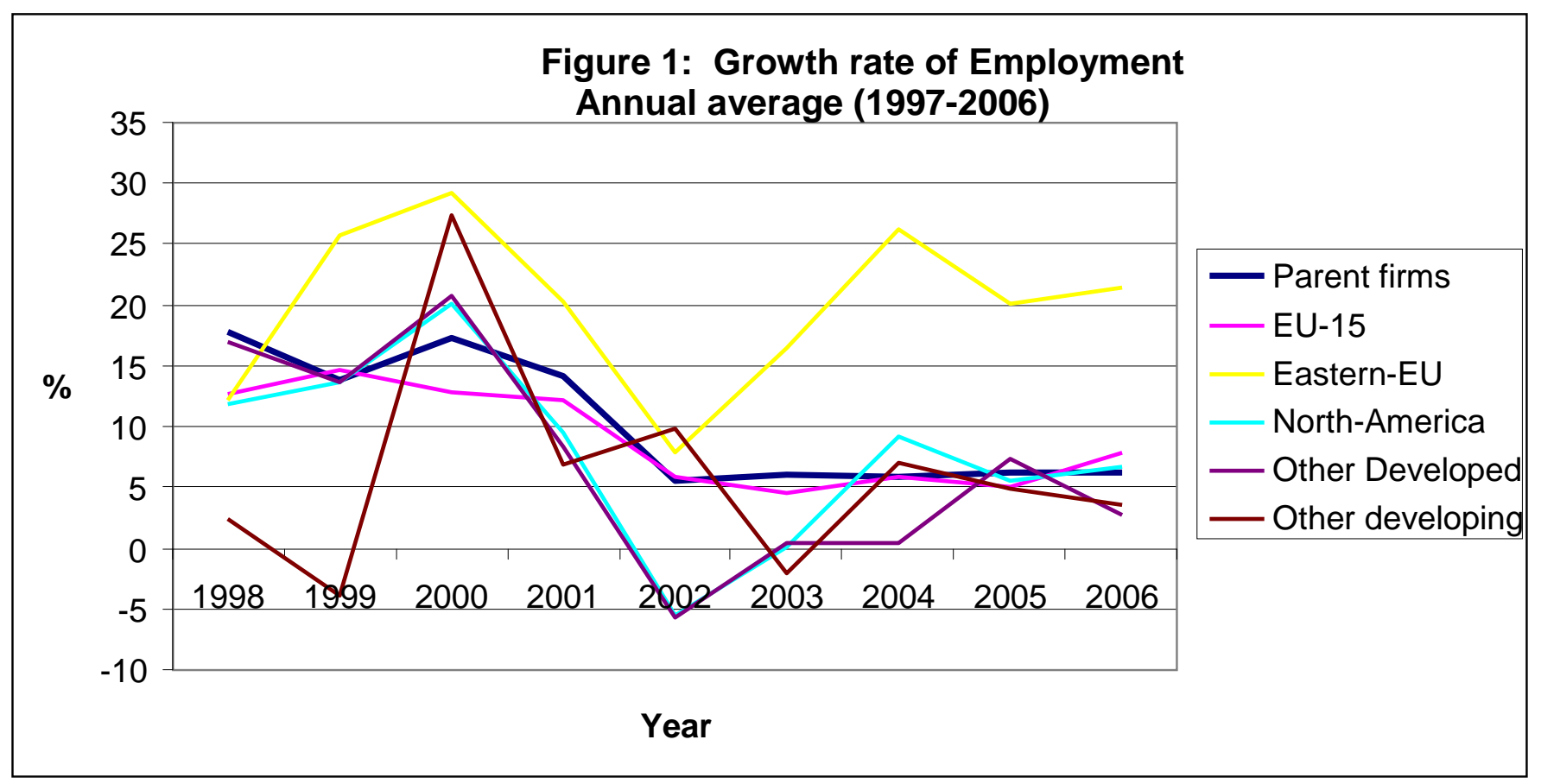

Source: Authors' calculation using the Orbis data 
Table 4 Average Labour Growth Rate (\% over the period 1997-2006)

High-tech Manufacturing

\begin{tabular}{|c|c|c|c|c|c|c|c|c|}
\hline & Belgium & France & Germany & Netherlands & Sweden & UK & Japan & United States \\
\hline Parent & 5.9 & 3.5 & 3.4 & 2.8 & 5.9 & 0.9 & 0.6 & 4.6 \\
\hline Subsidiaries & 4.1 & 7.1 & 7.4 & 6.3 & 6.7 & 8.6 & 7.5 & 5.0 \\
\hline \multicolumn{9}{|l|}{ Of which in } \\
\hline EU 15 & 1.5 & 6.0 & 4.9 & 6.1 & 2.6 & 9.0 & 6.8 & 6.0 \\
\hline Other Europe & -- & 0.0 & 1.1 & 0.0 & 1.9 & 5.9 & -- & 4.4 \\
\hline Eastern Europe & 35.1 & 12.3 & 28.6 & 9.5 & 21.5 & -3.7 & -- & 8.2 \\
\hline North America & 5.3 & 12.8 & 4.7 & 2.5 & 5.5 & 11.0 & 9.1 & 2.2 \\
\hline Latin America & -- & 7.2 & 10.4 & -3.1 & -- & -- & 6.8 & 0.1 \\
\hline Asia & 28.6 & -4.6 & -- & 0.0 & 3.4 & -- & 12.8 & 3.4 \\
\hline Africa \& M.E. & -- & 0.0 & 1.7 & -4.7 & -- & -- & -- & -- \\
\hline Oceania & -- & 6.0 & -- & -- & -- & 0.1 & 3.8 & -- \\
\hline & \multicolumn{8}{|c|}{ High-tech Services } \\
\hline Parent & 26.9 & 16.7 & 11.9 & 15.5 & 22.2 & 18.5 & 11.1 & 15.6 \\
\hline Subsidiaries & 8.1 & 12.9 & 11.3 & 16.2 & 15.1 & 10.0 & 6.8 & 11.6 \\
\hline \multicolumn{9}{|l|}{ Of which in } \\
\hline EU 15 & 6.7 & 9.2 & 7.5 & 17.6 & 16.1 & 10.0 & 10.2 & 12.6 \\
\hline Other Europe & 4.8 & -- & 9.8 & 0.4 & 12.0 & $\begin{array}{l}-0.8 \\
\end{array}$ & -- & 0.5 \\
\hline Eastern Europe & 3.5 & 28.8 & 24.7 & 23.0 & 18.7 & 13.8 & -- & 20.4 \\
\hline North America & -- & 9.2 & 15.0 & -- & 50.9 & 14.8 & -- & 7.4 \\
\hline Latin America & -- & -- & -- & -- & -8.9 & 2.9 & -- & -0.6 \\
\hline Asia & -- & -- & -- & -- & -- & 13.8 & -- & 33.8 \\
\hline Africa \& M.E. & -- & -- & -- & -- & -- & -- & -- & -- \\
\hline Oceania & 2.0 & -- & -- & -- & -- & -- & -- & 13.1 \\
\hline
\end{tabular}

Note: Some parent firm do not have a presence in certain regions or subsidiaries with observation of only 1 year, thus --.

Source: Authors' calculation using the Orbis data 
Table 5 Average Labour Growth Rate over the period 1997-2006

(Parent firms in Low-tech industries)

\begin{tabular}{|c|c|c|c|c|c|c|c|c|}
\hline & \multicolumn{8}{|c|}{ High-tech Manufacturing } \\
\hline & Belgium & France & Germany & Netherlands & Sweden & UK & Japan & United States \\
\hline Parent & 4.4 & 2.2 & 1.6 & 4.3 & 4.7 & 2.1 & 1.1 & 4.5 \\
\hline Subsidiaries & 4.9 & 6.7 & 7.5 & 5.6 & 4.8 & 5.6 & 6.6 & 4.0 \\
\hline \multicolumn{9}{|l|}{ Of which in } \\
\hline EU 15 & 3.7 & 5.8 & 5.6 & 5.0 & 3.6 & 4.6 & 5.8 & 3.7 \\
\hline Other Europe & 2.8 & 2.4 & 3.0 & 2.4 & 3.7 & 3.3 & 1.4 & 1.1 \\
\hline Eastern Europe & 11.8 & 13.5 & 16.1 & 9.7 & 11.9 & 12.6 & 20.3 & 10.4 \\
\hline North America & 5.3 & 6.4 & 7.7 & 6.4 & 8.2 & 7.4 & 7.7 & 1.4 \\
\hline Latin America & 0.5 & 7.9 & 10.7 & 17.7 & 4.7 & 6.4 & 9.8 & 9.5 \\
\hline Asia & -0.4 & 8.2 & 14.3 & 5.2 & 11.0 & 21.5 & 12.0 & 7.2 \\
\hline Africa \& M.E. & 11.8 & 13.0 & 12.8 & 12.0 & 0.0 & 1.1 & -3.4 & 8.1 \\
\hline Oceania & -- & 3.2 & -- & -- & -7.7 & 13.0 & -- & -- \\
\hline & \multicolumn{8}{|c|}{ High-tech Services } \\
\hline Parent & 11.3 & 7.6 & 4.6 & 7.9 & 9.9 & 8.7 & 1.7 & 12.5 \\
\hline Subsidiaries & 7.1 & 10.1 & 8.7 & 9.6 & 9.0 & 10.2 & 6.9 & 9.0 \\
\hline \multicolumn{9}{|l|}{ Of which in } \\
\hline EU 15 & 6.4 & 9.3 & 6.9 & 8.3 & 7.6 & 9.6 & 6.2 & 9.8 \\
\hline Other Europe & 1.0 & 4.6 & 4.1 & 5.0 & 8.9 & 8.1 & 4.4 & 6.9 \\
\hline Eastern Europe & 15.0 & 16.8 & 16.1 & 16.6 & 15.1 & 16.1 & 11.1 & 11.7 \\
\hline North America & 11.2 & 9.0 & 9.0 & 7.7 & 5.7 & 11.0 & 8.2 & 4.3 \\
\hline Latin America & 3.0 & 8.2 & 12.5 & 7.0 & 6.9 & 7.1 & 17.8 & 6.9 \\
\hline Asia & 13.1 & 10.9 & 8.1 & 9.6 & 19.7 & 6.8 & 12.4 & 13.5 \\
\hline Africa \& M.E. & 16.6 & 10.6 & 37.6 & 7.6 & -- & 1.3 & 24.5 & -1.1 \\
\hline Oceania & 3.7 & 10.5 & -- & 3.4 & -- & 1.1 & -16.6 & 0.4 \\
\hline
\end{tabular}

Note: Some parent firm do not have a presence in certain regions or subsidiaries with observation of only 1 year, thus --.

Source: Authors' calculation using the Orbis data 
Table 6 Probit estimation

\begin{tabular}{|c|c|c|c|c|c|c|c|c|c|}
\hline & $\begin{array}{c}\text { Full } \\
\text { sample }\end{array}$ & Belgium & France & Germany & $\begin{array}{c}\text { Netherla } \\
\text { nds }\end{array}$ & Sweden & $\overline{\mathrm{UK}}$ & Japan & US \\
\hline Size & $\begin{array}{c}0.03 * * * \\
(0.01)\end{array}$ & $\begin{array}{c}0.22 * * * \\
(0.03)\end{array}$ & $\begin{array}{c}0.32 * * * \\
(0.02)\end{array}$ & $\begin{array}{c}0.13 * * * \\
(0.04)\end{array}$ & $\begin{array}{c}0.19 * * * \\
(0.04)\end{array}$ & $\begin{array}{c}0.06^{* *} \\
(0.02)\end{array}$ & $\begin{array}{c}-0.07 * * * \\
(0.02)\end{array}$ & $\begin{array}{c}0.29 * * * \\
(0.04)\end{array}$ & $\begin{array}{c}0.30 * * * * \\
(0.06)\end{array}$ \\
\hline $\begin{array}{l}\text { Labour } \\
\text { productivity }\end{array}$ & $\begin{array}{c}0.14 * * * \\
(0.01) \\
\end{array}$ & $\begin{array}{c}0.40^{* * * *} \\
(0.03) \\
\end{array}$ & $\begin{array}{c}0.44 * * * \\
(0.02) \\
\end{array}$ & $\begin{array}{l}0.12 * * \\
(0.05) \\
\end{array}$ & $\begin{array}{c}0.34 * * * \\
(0.04) \\
\end{array}$ & $\begin{array}{c}0.39 * * * \\
(0.03) \\
\end{array}$ & $\begin{array}{c}0.09 * * * \\
(0.03) \\
\end{array}$ & $\begin{array}{c}0.58^{* * *} * \\
(0.05) \\
\end{array}$ & $\begin{array}{c}0.37 * * * \\
(0.07) \\
\end{array}$ \\
\hline Capital intensity & $\begin{array}{c}0.03 * * * \\
(0.01)\end{array}$ & $\begin{array}{c}0.28 * * * \\
(0.02)\end{array}$ & $\begin{array}{c}0.22 * * * \\
(0.01)\end{array}$ & $\begin{array}{c}0.11 * * * \\
(0.03)\end{array}$ & $\begin{array}{c}0.06 \text { *** } \\
(0.02)\end{array}$ & $\begin{array}{c}0.25 \text { *** } \\
(0.01)\end{array}$ & $\begin{array}{c}0.09 \text { *** } \\
(0.01)\end{array}$ & $\begin{array}{c}0.22 * * * \\
(0.03)\end{array}$ & $\begin{array}{c}0.10 * * * \\
(0.04)\end{array}$ \\
\hline Profitability & $\begin{array}{c}0.14 * * * \\
(0.01)\end{array}$ & $\begin{array}{l}0.04 * \\
(0.03)\end{array}$ & $\begin{array}{l}-0.00 \\
(0.01)\end{array}$ & $\begin{array}{c}0.01 \\
(0.03)\end{array}$ & $\begin{array}{c}0.05 \\
(0.04)\end{array}$ & $\begin{array}{c}0.00 \\
(0.02)\end{array}$ & $\begin{array}{c}0.08 \text { *** } \\
(0.02)\end{array}$ & $\begin{array}{c}0.11 \text { *** } \\
(0.03)\end{array}$ & $\begin{array}{c}0.01 \\
(0.04)\end{array}$ \\
\hline Cash & $\begin{array}{c}0.10^{* * * *} \\
(0.01)\end{array}$ & $\begin{array}{l}-0.01 \\
(0.03)\end{array}$ & $\begin{array}{c}0.05 * * * \\
(0.02)\end{array}$ & $\begin{array}{c}-0.04 * * * \\
(0.01)\end{array}$ & $\begin{array}{c}0.06 \\
(0.04)\end{array}$ & $\begin{array}{c}0.09 \text { *** } \\
(0.03)\end{array}$ & $\begin{array}{c}0.28 * * * \\
(0.03)\end{array}$ & $\begin{array}{c}0.14 * * * \\
(0.04)\end{array}$ & $\begin{array}{c}0.08 * * * \\
(0.03)\end{array}$ \\
\hline Constant & $\begin{array}{c}-3.15 * * * \\
(0.04)\end{array}$ & $\begin{array}{c}-3.07 * * * \\
(0.14) \\
\end{array}$ & $\begin{array}{c}-4.10 * * * \\
(0.09)\end{array}$ & $\begin{array}{l}-1.22 \\
(0.29)\end{array}$ & $\begin{array}{c}-3.63 * * * \\
(0.23) \\
\end{array}$ & $\begin{array}{c}-2.48 * * * \\
(0.13)\end{array}$ & $\begin{array}{c}-2.46^{* * *} * \\
(0.14)\end{array}$ & $\begin{array}{c}-8.09 * * * \\
(32.14) \\
\end{array}$ & $\begin{array}{c}-5.40 * * * \\
(0.44)\end{array}$ \\
\hline Prob > chi2 & 0.00 & 0.00 & 0.00 & 0.00 & 0.00 & 0.00 & 0.00 & 0.00 & 0.00 \\
\hline Pseudo R2 & 0.17 & 0.19 & 0.31 & 0.06 & 0.20 & 0.17 & 0.16 & 0.44 & 0.23 \\
\hline Log likelihood & $-26,481$ & $-2,292$ & $-6,694$ & -803 & $-1,069$ & 2,936 & $-3,001$ & $-1,718$ & -368 \\
\hline Observations & 62,229 & 4,507 & 20,789 & 1,291 & 1959 & 5,783 & 5,195 & 21,310 & 1,395 \\
\hline
\end{tabular}

Note: Standard errors in parenthesis. All variables are contemporaneous.

$* * *, * *, *$ denote significance at the $1 \%, 5 \%$ and $10 \%$ level, respectively.

Full sets of industry, time dummies (and country dummies for full sample) are included.

Table 7 Sector specific probit estimates

\begin{tabular}{|c|c|c|c|c|c|c|}
\hline & \multicolumn{2}{|c|}{ Full sample } & \multicolumn{2}{|c|}{ Manufacturing } & \multicolumn{2}{|c|}{ Services } \\
\hline & Spec 1 & Spec 2 & Spec 1 & Spec 2 & Spec 1 & Spec 2 \\
\hline Size & $\begin{array}{c}0.28 * * * \\
(22.95)\end{array}$ & $\begin{array}{c}0.29 * * * \\
(21.16)\end{array}$ & $\begin{array}{c}0.41 * * * \\
(23.16)\end{array}$ & $\begin{array}{c}0.42 * * * \\
(21.95)\end{array}$ & $\begin{array}{c}0.15 * * * \\
(8.34)\end{array}$ & $\begin{array}{c}0.13 * * * \\
(6.58)\end{array}$ \\
\hline $\begin{array}{l}\text { Labour } \\
\text { productivity }\end{array}$ & $\begin{array}{c}0.44 * * * \\
(24.9)\end{array}$ & $\begin{array}{c}0.43^{* * * *} \\
(20.00)\end{array}$ & $\begin{array}{c}0.50 * * * \\
(19.24)\end{array}$ & $\begin{array}{c}0.46^{* * * *} \\
(15.18)\end{array}$ & $\begin{array}{c}0.33 \text { **** } \\
(13.81)\end{array}$ & $\begin{array}{c}0.33 * * * \\
(10.74)\end{array}$ \\
\hline Capital intensity & $\begin{array}{c}0.23 * * * \\
(27.83) \\
\end{array}$ & $\begin{array}{c}0.23 * * * \\
(25.32) \\
\end{array}$ & $\begin{array}{c}0.18 * * * \\
(13.74) \\
\end{array}$ & $\begin{array}{c}0.18 * * * \\
(12.71) \\
\end{array}$ & $\begin{array}{c}0.26 * * * \\
(23.75) \\
\end{array}$ & $\begin{array}{c}0.27 * * * \\
(21.57) \\
\end{array}$ \\
\hline Profitability & $\begin{array}{c}0.06 * * * \\
(6.53)\end{array}$ & $\begin{array}{c}0.06 * * * \\
(5.37)\end{array}$ & $\begin{array}{c}0.04 * * * \\
(2.98)\end{array}$ & $\begin{array}{l}0.03 * \\
(1.93)\end{array}$ & $\begin{array}{c}0.09 * * * \\
(6.19)\end{array}$ & $\begin{array}{c}0.10 * * * \\
(5.95)\end{array}$ \\
\hline Cash & $\begin{array}{c}0.04 * * * \\
(7.46)\end{array}$ & $\begin{array}{c}0.04 * * * \\
(7.42)\end{array}$ & $\begin{array}{c}0.04 * * * \\
(5.73)\end{array}$ & $\begin{array}{c}0.04 * * * \\
(5.55)\end{array}$ & $\begin{array}{c}0.04 * * * \\
(4.88)\end{array}$ & $\begin{array}{c}0.05^{* * * *} \\
(4.84)\end{array}$ \\
\hline Average wage & & $\begin{array}{c}0.09 * * * \\
(2.80)\end{array}$ & & $\begin{array}{c}0.11 * * * \\
(2.68)\end{array}$ & & $\begin{array}{l}0.12 * * \\
(2.21)\end{array}$ \\
\hline Constant & $\begin{array}{c}-5.53 * * * * \\
(42.71)\end{array}$ & $\begin{array}{c}-4.91 * * * \\
(-29.95)\end{array}$ & $\begin{array}{c}-5.26 * * * \\
(26.82)\end{array}$ & $\begin{array}{c}-5.45^{* * * *} \\
(25.57)\end{array}$ & $\begin{array}{c}-3.97 * * * \\
(21.22)\end{array}$ & $\begin{array}{c}-4.23 * * * * \\
(16.19)\end{array}$ \\
\hline Prob > chi2 & 0.00 & 0.00 & 0.00 & 0.00 & 0.00 & 0.00 \\
\hline Pseudo R2 & 0.3962 & 0.3656 & 0.4339 & 0.3887 & 0.3328 & 0.2966 \\
\hline Log likelihood & -3034 & -7634 & -4768 & -4192 & -4141 & -3340 \\
\hline Observations & 25652 & 19177 & 13145 & 10112 & 12507 & 9065 \\
\hline
\end{tabular}

Note: Standard errors in parenthesis. All variables are lagged one period.

$* * *, * *, *$ denote significance at the $1 \%, 5 \%$ and $10 \%$ level, respectively.

Full sets of industry, time dummies (and country dummies for full sample) are included. 


\section{Appendix A:}

Table A2 Country by Country Classification

\begin{tabular}{|c|c|c|c|}
\hline \multicolumn{4}{|l|}{ High Income } \\
\hline Australia & Greece & Malta & United Kingdom \\
\hline Austria & Greenland & Monaco & United States \\
\hline Belgium & Iceland & Netherlands & Switzerland \\
\hline Canada & Ireland & New Zealand & Japan \\
\hline Denmark & Israel & Norway & Germany \\
\hline Finland & Italy & Portugal & \\
\hline France & Spain & Sweden & \\
\hline \multicolumn{4}{|l|}{ Low Income } \\
\hline Estonia & Guinea & Somalia & Congo, Rep. \\
\hline Czech Republic & Guinea-Bissau & Sudan & Cuba \\
\hline Hong Kong, China & Haiti & Tajikistan & Djibouti \\
\hline Korea, Rep. & India & Tanzania & Dominican Republic \\
\hline Kuwait & Kenya & Timor-Leste & Ecuador \\
\hline Macao, China & Korea, Dem. Rep. & Togo & Egypt, Arab Rep. \\
\hline Taiwan, China & Kyrgyz Republic & Uganda & El Salvador \\
\hline United Arab Emirates & Lao PDR & Uzbekistan & Fiji \\
\hline Puerto Rico & Liberia & Vietnam & Georgia \\
\hline Qatar & Madagascar & Yemen, Rep. & Guatemala \\
\hline Saudi Arabia & Malawi & Zambia & Guyana \\
\hline Singapore & Mali & Zimbabwe & Honduras \\
\hline Slovenia & Mauritania & Albania & Indonesia \\
\hline Bangladesh & Mongolia & Algeria & Iran, Islamic Rep. \\
\hline Benin & Mozambique & Angola & Iraq \\
\hline Burkina Faso & Myanmar & Armenia & Jamaica \\
\hline Burundi & Nepal & Azerbaijan & Jordan \\
\hline Cambodia & Niger & Belarus & Macedonia, FYR \\
\hline Central African & Nigeria & Bhutan & Moldova \\
\hline Republic & Pakistan & Bolivia & Morocco \\
\hline Chad & Papua New Guinea & Bosnia and & Namibia \\
\hline Comoros & Rwanda & Herzegovina & Nicaragua \\
\hline Congo, Dem. Rep. & São Tomé and Principe & Cameroon & Paraguay \\
\hline Côte d'Ivoire & Senegal & Cape Verde & Peru \\
\hline Eritrea & Sierra Leone & China & Philippines \\
\hline Ethiopia & Hungary & Colombia & Samoa \\
\hline Gambia, The & Kazakhstan & Sri Lanka & Costa Rica \\
\hline Ghana & Latvia & Suriname & Croatia \\
\hline Serbia & Lebanon & Swaziland & Panama \\
\hline Slovak Republic & Libya & Syrian Arab Republic & Poland \\
\hline South Africa & Lithuania & Thailand & Romania \\
\hline Uruguay & Malaysia & Tonga & Russian Federation \\
\hline Venezuela, RB & Mauritius & Tunisia & Montenegro \\
\hline Ukraine & Mexico & Turkmenistan & Oman \\
\hline Argentina & Chile & Bulgaria & Brazil \\
\hline \multicolumn{4}{|l|}{ Tax havens } \\
\hline Antigua & Bermuda & Isle of Man & St Kitts and Nevis \\
\hline Bahamas & Channel Islands & Liechtenstein & St Lucia \\
\hline Bahrain & Cyprus & Luxembourg & St Vincent \\
\hline Barbados & Gibraltar & Macao & Turks and Caicos - \\
\hline Belize & Grenada & Netherlands Antilles & Islands \\
\hline
\end{tabular}

Source: Harrison and McMillan (2007); Simpson (2007) 